\title{
Knowledge and Attitude of Teachers In Kindergarten about Children with Epilepsy
}

Hala Elgarawany*

\begin{abstract}
The aim of the present work was to examine the knowledge and attitude of teachers in kindergartens about children with epilepsy. Descriptive cross-section research design was used. The study was conducted in six experimental governmental schools represent the six educational areas in Alexandria. The sample of the study was 167 teachers. Data was collected through distributing self completed questionnaires in each school included in the study. There were significant relations between level of education and positive attitude towards epileptic children. There was signification relation between years of experiences and correct knowledge about epilepsy in children.
\end{abstract}

\section{INTRODUCTION}

Seizures are common in the pediatric usually unpredictable. The cumulative age group and occur in approximately $10 \% \quad$ lifetime incidence of epilepsy is $3 \%$; more of children. Less than one third of seizures than half of the cases begin in childhood. in children are caused by epilepsy; a The annual prevalence of epilepsy is low condition in which seizers are triggered recurrently from within the brain. Epilepsy (0.5-0.8\%) because many children outgrow is a chronic disorder, in which the epilepsy. ${ }^{(1)}$

Epilepsy significantly affects learning indispensable feature is recurrence of and behavior. Children with epilepsy are seizures that are typically unprovoked and particularly vulnerable to educational ${ }^{*}$ Assistant Prof. Child Health Kindergarten Collage University of Alexandria 
problems and resultant academic respect, and they build a picture of underachievement. $^{(2)}$ Co-morbidities like themselves. Enthusiasm or lack of cognitive and behavioral problems enthusiasm for school elevates or breaks contribute significantly to problems at the expectations of any child, especially school.(2) These learning difficulties seem those affected by chronic illness; that is to be caused by a variety of factors their self-image can be enhanced or including cognitive dysfunction, specific destroyed.(5) The quality of life of school learning disabilities and behavioral children with epilepsy may seriously be problems. These problems in turn, may be related to organic factors such as underlying brain pathology, frequent seizures and/or paroxysmal EEG activity and mediation side effects, and nonorganic factors such as overprotection by parents, decreased self-esteem and poor motivation. (3-4) $^{-4}$

School is the second most important social environment for the child after family. There, with the acquisition of knowledge and skills, the child develops social skills as well. Through interaction with their peers, children satisfy their development task of emancipation, they develop selfaffected by the altitude of their families and school environment if the people around them are unaware of or uneducated about their condition. This fact renders the children with epilepsy helpless, fragile, and unconfident. Children having seizures may distract their teachers who do not receive specific training about epilepsy during their education. Moreover, the teachers may feel desperate not knowing how to handle the situation.(6) On the other hand different studies have shown that teachers have limited understanding of common chronic childhood illness. ${ }^{(5)}$

One of the major difficulties in 
developing countries is in giving some degree of priority to non-communicable diseases like epilepsy in the midst of competing health problems such as infections, malnutrition, unsafe drinking water and high maternal and child mortality. Teachers are important targets for health educational problems especially as good percentage of child's waking life is spent in school. During this time teachers have much influence on children and therefore have an important role to play in the management and surveillance of children with epilepsy. Teacher attitude and knowledge regarding childhood epilepsy is likely to influence the educational performance of children with the disease. ${ }^{(6)}$

The aim of present work was to examine the knowledge and attitude of teachers in kindergartens about children with epilepsy and, thus, gain information on how the teachers approach children with epilepsy in the course of their work.
Furthermore, this kind of study was to provide information for better understanding the social effects of epilepsy in children.

\section{MATERIAL AND METHODS}

\section{1- Study design:}

\section{Descriptive cross-section research} design was used to determine the knowledge and attitude of kindergarten teachers about epilepsy in children.

\section{2- Sample setting}

The study was conducted in six experimental governmental schools representing the six educational areas in Alexandria. Hoda-Sharawy school, Abokir experimental school, Balkis school, Karmoz school, Alagamy school and Alamreya school.

\section{3- Subject}

The sample of the study was 167 teachers chosen randomly from school sheets in the six schools included in the study (every second name). 


\section{Tools and methods}

Data was collected through distributing self completed questionnaires in each school included in the study. The questionnaire consists of 26 questions. The questionnaire consists of four main sections

- Personal details include: age, marital status, years experience and education.

- For knowledge assessment 12 questions.

- For familiarity assessment 4 questions.

- For attitude assessment 10 questions.

The questionnaire was developed following careful review of similar pervious studies. It was modified from two questionnaires. ${ }^{(7,8)}$

The questions were mainly answered by "Yes", "No", "Don't know". The areas covered by the questionnaire included:

1. Teacher personal details including age, years of teaching experiences and marital status.
2. General knowledge of the aetiology, presentation, treatment, and outcome of school children with epilepsy.

3. Previous experience of epilepsy in children, including personal encounters with epileptic children and previous specific training on epilepsy.

4. Views regarding possible learning difficulties in epileptic children and the most appropriate school placement for them.

5. Appropriate restrictions of activity for children who had epilepsy, appropriate careers for them and views regarding the difficulties that might be encountered by them on leaving school.

6. First-aid treatment of epileptic fits and views regarding the administration of rectal diazepam at school.

7. Overall confidence of the teachers when presented with a child with epilepsy.

The questionnaire was tested on 20 
teachers as pilot and amended for clarity by simplify some questions. The score of each section was calculated by summing the scores of its questions. Cronebach alpha coefficient of internal consistency was used to estimate the reliability of the questionnaire. Alpha coefficient was 0.789. Verbal consent was obtained from the principles and head teachers before the questionnaires were distributed to school teachers. The questionnaires were analysed using SPSS statistical computer package, frequencies were done and associations determined by using the $\mathrm{Chi}^{2}$ test.

\section{RESULTS}

Table 1: shows the main demographic features of the teachers. As regards the age $18.6 \%$ of the sample were under 25 years, $16.2 \%$ between $25-<30$ year, $31.1 \%$ between $30-<35$ year and $34.1 \%$ were 35 years or more. Also $34.7 \%$ of the sample were single and $65.3 \%$ were married. As regards experience, $14.4 \%$ have less than 5 years, $50.3 \%$ have $5-10$ years experience and $35.3 \%$ have more than 10 years. As regard education level $23.4 \%$ were secondary, $48.5 \%$ were university and $28.1 \%$ were post graduate.

Table 2: shows the familiarity of teachers to epilepsy as $27.5 \%$ of sample have tough a child with epilepsy, $43.7 \%$ have epileptic relative or friend, $36.5 \%$ can do the first-aid for epileptic child and only $9.6 \%$ can put rectal suppository during convulsion.

Table 3: shows teachers response to questions on knowledge about epilepsy. About $58.1 \%$ of the sample knew the definition of epilepsy. As regards the causes of epilepsy, $11.4 \%$ of the sample agreed that epilepsy is an infectious disease, $16.7 \%$ agreed that epilepsy is psychiatric disease, $56.3 \%$ agreeds that epilepsy runs in families. As regard treatment of epilepsy $43.7 \%$ of the sample 
agreed that drugs used to treat epilepsy may cause drowsiness and $50.9 \%$ agreed that epilepsy can be cured with medicine.

As regards diagnosis of epilepsy $60.5 \%$ of the sample agreed that diagnosis of epilepsy by E. E. G. and only $9.6 \%$ agreed that the incidence of epilepsy in school children was between $0.5 \%-1 \%$.

Table (4) shows the attitude of teachers towards epilepsy. Results revealed that $70.7 \%$ of teachers have positive attitude towards epileptic child but $67.1 \%$ of the sample thought that epileptic child may make problems in the class and $47.3 \%$ though that epileptic child have behavior problems. As regards learning performance of epileptic children, $77.8 \%$ of the sample agree that epileptic children can learn in regular schools, only $15 \%$ of the sample objected to having a pupil with epilepsy in the class, while $41.9 \%$ thought that epileptic child may have learning problems and $70.7 \%$ of the sample allowed epileptic child to participate in activities.

Table 5 shows the relation between teachers' attitude towards epilepsy and levels of education. There was significant relation between level of education and positive attitude towards epileptic children.

Table 6 shows the relation between teachers' knowledge and years of experience. There was signification relation between years of experiences and correct knowledge about epilepsy in children. 
Table 1: The main demographic features of the teachers

\begin{tabular}{|l|c|c|}
\hline \multirow{2}{*}{ Character } & \multicolumn{2}{|c|}{$\mathbf{n = 1 6 7}$} \\
\cline { 2 - 3 } & No. & $\%$ \\
\hline Age & & \\
$<25$ & 31 & 18.6 \\
\hline $25-<30$ & 27 & 16.2 \\
\hline $30-<35$ & 52 & 31.1 \\
\hline $35^{+}$ & 57 & 34.1 \\
\hline Marital statues & & 34.7 \\
\hline Single & 58 & 65.3 \\
\hline Married & 109 & 14.4 \\
\hline $\begin{array}{l}\text { Experience } \\
\text { Less than 5 years }\end{array}$ & 24 & 50.3 \\
\hline $5-10$ years & 84 & 35.3 \\
\hline More than 10 years & 59 & 23.4 \\
\hline $\begin{array}{l}\text { Education level } \\
\text { Secondary }\end{array}$ & 39 & 48.5 \\
\hline University & 81 & 28.1 \\
\hline Post graduate & 47 & \\
\hline
\end{tabular}

Table 2: Familiarity of teachers to epilepsy:

\begin{tabular}{||l|c|c|c|c|c|c|}
\hline \multirow{2}{*}{ Areas of familiarity } & \multicolumn{2}{|c|}{ Yes } & \multicolumn{3}{c|}{ No } & \multicolumn{3}{|c|}{$\begin{array}{c}\text { Don't } \\
\text { know }\end{array}$} \\
\cline { 2 - 8 } & No. & $\%$ & No. & $\%$ & No. & $\%$ \\
\hline -Have you ever tough a child with epilepsy & 46 & 27.5 & 117 & 70.1 & 4 & 2.4 \\
\hline -*Have you a friend or relative of epilepsy & 73 & 43.7 & 89 & 53.3 & 4 & 2.4 \\
\hline $\begin{array}{l}\text {-Do you think that you can do first aid for } \\
\text { epileptic students }\end{array}$ & 61 & 36.5 & 73 & 43.7 & 33 & 19.8 \\
\hline $\begin{array}{l}\text {-Do you can put supporting for conductive } \\
\text { treatment in epileptic child }\end{array}$ & 16 & 9.6 & 64 & 38.3 & 87 & 52.1 \\
\hline
\end{tabular}

${ }^{*} n=167$ but one teacher didn't answer the question. 
Table 3: Teachers' response to questions on knowledge about of epilepsy

\begin{tabular}{|l|c|c|c|c|c|c||}
\hline \multirow{2}{*}{ Teachers' general knowledge $(\mathbf{n}=\mathbf{1 6 7})$} & \multicolumn{2}{|c|}{ Yes } & \multicolumn{2}{c|}{ No } & \multicolumn{2}{c|}{$\begin{array}{c}\text { Don't } \\
\text { know }\end{array}$} \\
\cline { 2 - 8 } & No. & $\%$ & No. & $\%$ & No. & $\%$ \\
\hline 1-Do you know the definition of epilepsy & 97 & 58.1 & 49 & 29.3 & 21 & 12.6 \\
\hline 2-Epilepsy is an infectious disease & 19 & 11.4 & 130 & 77.8 & 18 & 10.8 \\
\hline 3-Epilepsy is a psychiatric disease & 28 & 16.7 & 111 & 66.5 & 28 & 16.8 \\
\hline 4-All children who have fit have Epilepsy & 20 & 11.9 & 108 & 64.7 & 39 & 23.4 \\
\hline 5-Epilepsy can be cured with medicine & 69 & 41.3 & 32 & 19.2 & 66 & 39.5 \\
\hline 6-Epilepsy runs in families & 94 & 56.3 & 34 & 20.4 & 39 & 23.4 \\
\hline 7- Epileptic children have educational problems & 94 & 56.3 & 4 & 2.4 & 69 & 41.3 \\
\hline 8-Epileptic can occur at any time & 61 & 36.5 & 49 & 29.3 & 57 & 34.1 \\
\hline 9-Drugs used to treat epilepsy can cause drowsiness & 73 & 43.7 & 13 & 7.8 & 81 & 48.5 \\
\hline 10-Epilepsy can be cured & 85 & 50.9 & 16 & 9.6 & 66 & 39.5 \\
\hline 11-Diagnosis of epilepsy by E. E. G & 101 & 60.5 & 10 & 6.0 & 56 & 33.5 \\
\hline 12-Incidence of epilepsy in school children 0.5-1\%. & 16 & 9.6 & 4 & 2.4 & 147 & 88.0 \\
\hline
\end{tabular}

Table 4: Attitude of teachers towards epilepsy

\begin{tabular}{|l|c|c|c|c|c|c||}
\hline \multicolumn{1}{|c|}{ Areas of attitude } & \multicolumn{5}{c|}{$\begin{array}{c}\text { Response } \\
\text { (n=167) }\end{array}$} \\
\cline { 2 - 7 } & \multicolumn{2}{|c|}{ Yes } & \multicolumn{3}{c|}{ No } & \multicolumn{3}{|c|}{$\begin{array}{c}\text { Don't } \\
\text { know }\end{array}$} \\
\cline { 2 - 8 } & No. & $\%$ & No. & $\%$ & No. & $\%$ \\
\hline $\begin{array}{l}\text { 1-Do you have positive attitudes towards epileptic } \\
\text { child as other children }\end{array}$ & 118 & 70.6 & 31 & 18.6 & 18 & 10.8 \\
\hline $\begin{array}{l}\text { 2-Do you think that epileptic child will make problem } \\
\text { in the class }\end{array}$ & 112 & 67.1 & 49 & 29.3 & 6 & 3.6 \\
\hline $\begin{array}{l}\text { 3-Do you think that epileptic child have behavior } \\
\text { problems }\end{array}$ & 79 & 47.3 & 55 & 32.9 & 33 & 19.8 \\
\hline $\begin{array}{l}\text { 4-Do you think that epileptic child have learning } \\
\text { problems }\end{array}$ & 70 & 41.9 & 52 & 31.1 & 45 & 26.9 \\
\hline $\begin{array}{l}\text { 5-Should children with epilepsy be allowed to } \\
\text { participate in regular schools }\end{array}$ & 130 & 77.8 & 7 & 4.2 & 30 & 18.0 \\
\hline $\begin{array}{l}\text { 6-Should children with epilepsy be allowed to } \\
\text { participate in activities. }\end{array}$ & 118 & 70.7 & 19 & 11.4 & 30 & 17.9 \\
\hline $\begin{array}{l}\text { 7-Do you think that a pupil with epilepsy may be as } \\
\text { intelligent as others }\end{array}$ & 103 & 61.7 & 16 & 9.6 & 48 & 28.7 \\
\hline $\begin{array}{l}\text { 8-Do you agree that your child make a friendship } \\
\text { with an epileptic child }\end{array}$ & 124 & 74.3 & 19 & 11.4 & 24 & 14.4 \\
\hline $\begin{array}{l}\text { 9-Do you agree that epileptic child live alone } \\
\text { 10-Do you object to having a pupil with epilepsy in } \\
\text { your class }\end{array}$ & 7 & 4.2 & 154 & 92.2 & 6 & 3.6 \\
\hline \hline
\end{tabular}




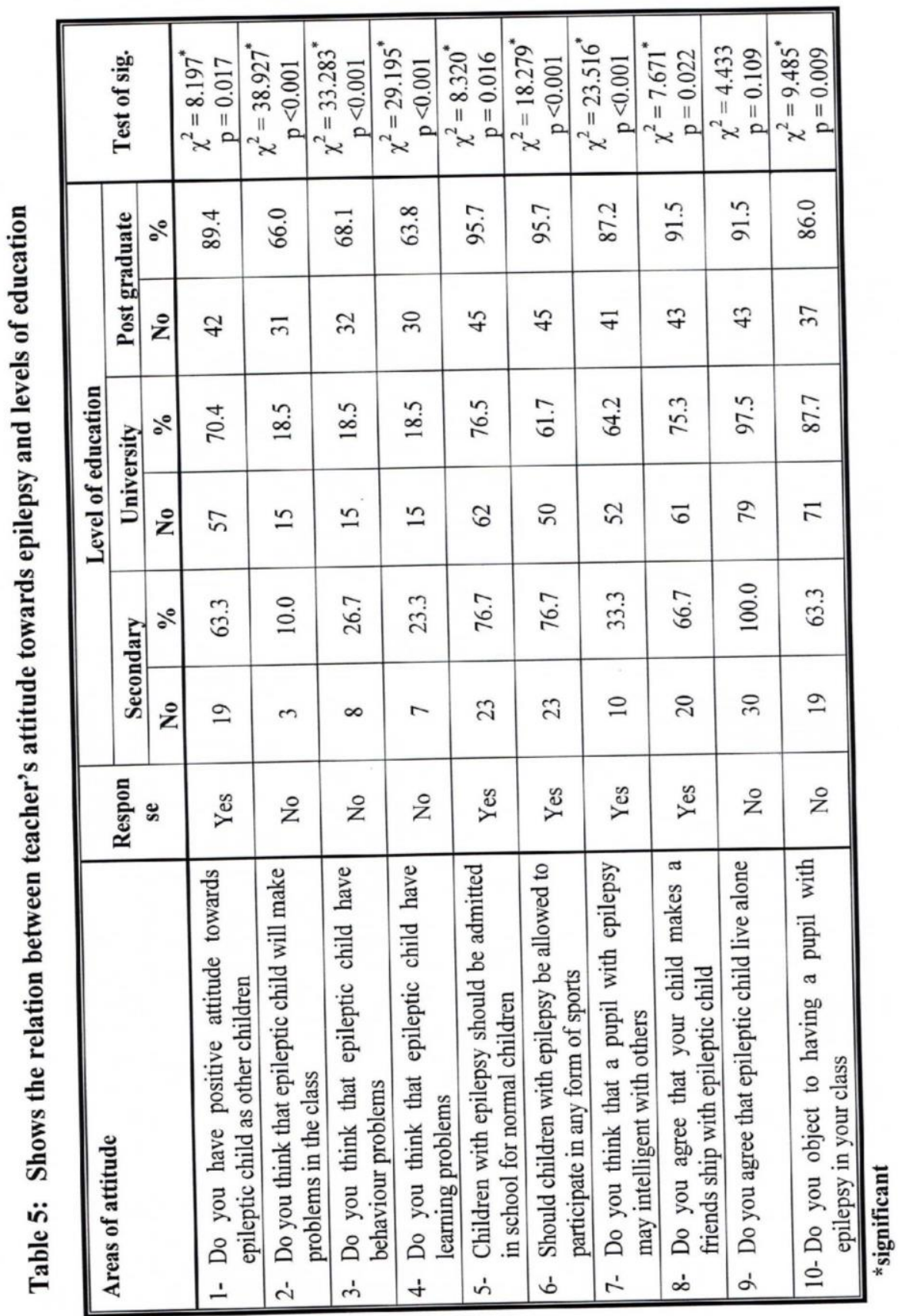


Table (6): The relations between knowledge of teachers about epilepsy and years of experience

\begin{tabular}{|c|c|c|c|c|c|c|c|c|}
\hline \multirow{3}{*}{ 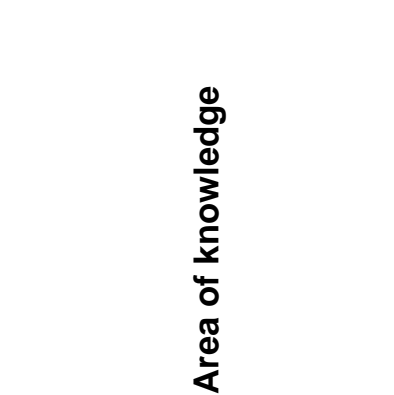 } & \multirow{3}{*}{ 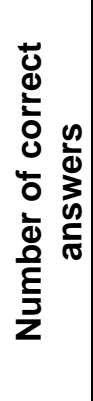 } & \multicolumn{6}{|c|}{ Years of experiences } & \multirow{3}{*}{$\frac{\widehat{a}}{x}$} \\
\hline & & \multicolumn{2}{|c|}{ 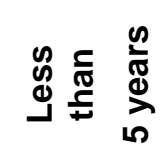 } & \multicolumn{2}{|c|}{ 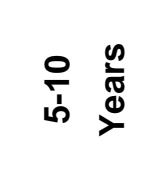 } & \multicolumn{2}{|c|}{ 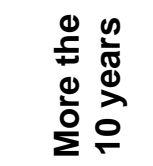 } & \\
\hline & & ì & ১ & i & ○ & $\dot{\mathbf{z}}$ & ○ & \\
\hline $\begin{array}{l}\text { 1-Do you know the } \\
\text { definition of epilepsy }\end{array}$ & 97 & 10 & 10.3 & 46 & 47.4 & 41 & 42.3 & $23.526^{*}(<0.001)$ \\
\hline $\begin{array}{l}\text { 2-Epilepsy is an infectious } \\
\text { disease }\end{array}$ & 130 & 20 & 15.4 & 63 & 48.5 & 47 & 36.2 & $21.800^{*}(<0.001)$ \\
\hline $\begin{array}{l}\text { 3-Epilepsy is a psychiatric } \\
\text { disease }\end{array}$ & 111 & 9 & 8.1 & 54 & 48.6 & 48 & 43.2 & $32.270^{*}(<0.001)$ \\
\hline $\begin{array}{l}\text { 4-All children who have fit } \\
\text { have Epilepsy }\end{array}$ & 108 & 6 & 5.6 & 53 & 49.1 & 49 & 45.4 & $37.722^{*}(<0.001)$ \\
\hline $\begin{array}{l}5 \text {-Epilepsy can be cured } \\
\text { with medicine }\end{array}$ & 69 & 17 & 24.6 & 30 & 43.5 & 22 & 31.9 & $3.739(0.154)$ \\
\hline 6-Epilepsy runs in families & 94 & 11 & 11.7 & 43 & 45.7 & 40 & 42.6 & $19.936^{*}(<0.001)$ \\
\hline $\begin{array}{l}\text { 7- Epileptic children have } \\
\text { educational problems }\end{array}$ & 94 & 10 & 1.6 & 44 & 46.8 & 40 & 42.6 & $22.043^{*}(<0.001)$ \\
\hline $\begin{array}{l}\text { 8-Epileptic can occur at } \\
\text { any time }\end{array}$ & 61 & 1 & 1.6 & 32 & 52.5 & 28 & 45.9 & $27.967^{*}(<0.001)$ \\
\hline $\begin{array}{l}\text { 9-Drugs used to treat } \\
\text { epilepsy can cause } \\
\text { drowsiness }\end{array}$ & 73 & 3 & 4.1 & 42 & 57.3 & 28 & 38.4 & $32.082^{*}(<0.001)$ \\
\hline 10-Epilepsy can be cured & 85 & 6 & 7.1 & 30 & 35.3 & 49 & 57.6 & $32.776^{*}(<0.001)$ \\
\hline $\begin{array}{l}\text { 11-Diagnosis of epilepsy } \\
\text { by E. E. G }\end{array}$ & 101 & 8 & 7.9 & 61 & 60.3 & 32 & 31.7 & $41.842^{*}(<0.001)$ \\
\hline $\begin{array}{l}\text { 12-Incidence of epilepsy in } \\
\text { school children } 0.5-1 \% \text {. }\end{array}$ & 16 & 0 & 0 & 5 & 31.3 & 11 & 68.8 & $2.250(0.134)$ \\
\hline
\end{tabular}

* Significant

\section{Discussion}

Among the many factors, organic or non life of an epileptic child at school are the organic, that can adversely influence knowledge and attitude of their teachers academic achievement and quality of toward them This issue has attended the 
interest of many investigators. To assess knowledge and attitude toward any subject the degree of familiarity with it is important. (3) Our study revealed that about $29.32 \%$ of teachers had been familiarized with epilepsy. Kaleyias et al (2005)(3) concluded that Greek teachers seen to have a reasonable degree of familiarity with epilepsy. Twenty-four percent have had an epileptic child in their class, at same time, a figure that is similar in other studies $^{(9,10)}$ although rates up to $41 \%^{(11)}$ and $57 \%{ }^{(12)}$ have been reported in other studies. This factor of familiarity with epilepsy seen to be an important as it was correlated with a higher degree of confidence in one's ability to help a convulsive child, a more accrete knowledge of the prognosis of epilepsy and more positive attitude toward the epileptic child. (3)

In our study the general knowledge score of epilepsy was $51.9 \%$. In Ngazl $2002^{(13)}$ study general knowledge of epilepsy with over all score of $59.2 \%$ while those in the paper of Bannon, et al was $70 \% .{ }^{(12)}$ It would appear from this study that this knowledge was acquired as a result of personal experience over the years rather than from structured training. These findings agree with our study as general knowledge increases significantly with years of experience.

Pala and Vanier (1997) found that teacher knowledge about epilepsy to be far from satisfactory. This was understandable as most teachers had not attended any educational programme on epilepsy. Also the teacher training program didn't cover child health problems. ${ }^{(14)}$

Many of the teachers in our study were not familiarized with the initial procedures in attending a person during seizure. The initial procedures adapted by some teachers who answered this question would be somehow inappropriate. Dantas et al (2001)(15) found the same result. In another study, ${ }^{(16)}$ half of the respondents 
who had experience with first-aid overwhelming majority $(70.7 \%)$ stated management of seizures also used that it is the same as to any other child. improper and potentially harmful This finding indicates a very high degree measures. These difficulties were of acceptance by their teachers despite probably related to poor educative that about $67.1 \%$ of teachers stated that programs in epilepsy. ${ }^{(17)}$ Also Ngozl epileptic child may make problems in the $(2002)^{(13)}$ stated that majority of teachers class room. This agree with another will engage in dangerous or harmful study which explain these findings and is practices if a child has a seizure in the not contradicting, however because classroom. Bannon et al (1992) when one looks at the specific problems concluded that the subject of generated by the epileptic child, the most administration ${ }^{(12)}$ of rectal suppository by common was "increase anxiety and teachers in school is fraught with responsibility for the teacher which is difficulty. These findings are in agree with reasonable and does not indicate our study as $9.6 \%$ of teachers only can administrate rectal suppository to child during convulsions.

In the present study teachers' attitude is significantly affected by teachers' education level. When teachers' were asked about their attitude toward the epileptic student, the rejection by the teacher. ${ }^{(3)}$ A high proportion of teachers (83.2\%) in Zimbabwe were ${ }^{(17)}$ willing to teach children with epilepsy as compared with $79.6 \%$ in the present study.

As regard the type of school the present study reveled that $77.8 \%$ of teachers agree that epileptic child be 
admitted to regular school as compared with $70 \%$ of teachers in $\operatorname{Lagos}^{(18)}$ and $95 \%$ of those in North Staffordshire. ${ }^{(12)}$ The same result was stated by Kaleyas et al (2005), ${ }^{(3)}$ while in a study among teachers in Thailand $15.1 \%$ of teachers preferred students with epilepsy to be placed in special classrooms and $9.8 \%$ wanted then to be cured and controlled before returning to their classrooms. ${ }^{(19)}$ In another study form Brazil $93-95 \%$ of the teachers didn't object to having a student with epilepsy in the class $^{(15)}$.

The issue of academic achievement in epilepsy still remain controversial Epilepsy in general may be associated with learning disabilities more frequently..$^{(18,19)}$ In the present study $41.9 \%$ of teachers believed that epileptic children have learning problems. Pale and Vankar (1997) stated that the teachers' perceptions about educational performance of the children with epilepsy were largely negative. ${ }^{(14)}$ Dantas et al $(2001)^{(15)}$ stated that some teachers in the study had disturbed about learning achievement of students with epilepsy. Kaleyias 2005,(3) stated that about $40 \%$ Greeks teachers think that epilepsy and learning problems coexist almost never or occasionally. The fact that epilepsy differs greatly in children must be taken into consideration, as some have severe learning problems and others do not. So teachers cannot have uniform conceptions of the capabilities of children with epilepsy. ${ }^{(20-22)}$

\section{RECOMMENDATIONS}

A well directed programme on causes and management of epileptic seizures will definitely improve the perception of epilepsy by teachers. Efforts should therefore be made, using possible avenues such as seminars, 
school health education programmes and

media which is an important source of information in most developing countries.

\section{REFERENCE}

1. Afify $M$, Kamel $M$, Mohamed $M$. Serum Ghrelin Level in Epileptic children, Alex J of Ped, 2008; 22(2): 231-5.

2. Guerrini R. Epilepsy in children Lancet, 2006; 367: 499524.

3. Kaleyias J. Tzoufi M, Kotslis C, Papavasiliou A, Diamantopoulos N. Knowledge and attitude of the Greek educational community toward epilepsy and the epileptic student. Epilepsy \& Behavior, 2005;15: 17986.

4. Dunn DW, Harezlak J, Ambrosius

WT, Austin JK, Hale B. Teacher assessment of behavior in children with new-onset seizures. Seizure, 2002; 11:169-75.

5. Prpic I, Korotaj Z, Vlasic I., Paucic Kirinic, E, Valerjev A, Tomac V. Teacher's pinions about capabilities and behavior of children with epilepsy. Epilepsy \& Behavior, 2003; 4: 142-45.

6. Bekiroglu N, Ozkan R, Gurses C, Arpac B, Dervent A. A study on awareness and attitude of teachers on epilepsy in Istanbul. Seizure, 2004; 13:517-22.

7. Tosetti MFV, Campos MA, Bauer CR. Knowledge about epilepsy among teachers and epileptic patients. Arq Neuropsiquiat, 1991; 49:255-9.
8. Millogo A, Siranyan S. Knowledge of epilepsy and attitudes towards the condition among school teachers in Bobo-Dioulasso (Burkina Faso). Epileptic Disord, 2004; 6: 21-6.

9. Kankirawatna P. Epilepsy awareness among school teachers in Thailand. Epilepsia, 1999; 40: 497-501.

10. Ojinnaka NC. Teachers' perception of epilepsy in Nigeria: a community based study. Seizure, 2002;11: 38691.

11. Gallhofer B. Epilepsy and its prejudice. Teachers' knowledge and opinions: are they a response to psychopathological phenomena? Psychopathology, 1984; 17: 186212.

12. Bannon MJ, Wilding C, Jones PW. Teachers' perceptions of epilepsy. Arch Dis Child, 1992; 67: 149-71.

13. Ngozl C. Teachers' perception of Epilepsy in Nigeria: a community - based study seizure 2002; 11: 386-91.

14. Pala I, Vankar G. Epilepsy and Teachers: a Survery. Indian J Pediatr 1997; 64: 211-4.

15. Dantas FG, Cariri GA, Cariri GA, Riberiro FAR. Knowledge and attitudes toward epilepsy among primary secondary and tertiary level teachers. Arq Neuropsiquiat, 2001; 59 (3-B) 712-6.

16. Kandirawatana P. Epilepsy awarenss among school teachers in Thailand. Epilepsia, 1999; 40: 497501.

17. Mielke J, Adamolekun B, Ball D, Mundanda T. Knowledge and attitudes of teachers toward epilepsy in Zimbabwe. Acta Neurologica Scandinavica, 1997; 96: 133-7. 
18. Danesi M A. Epilepsy and the secondary schools in Nigeria. Tropical and Geographical medicine, 1994; 46: 25-7.

19. Kankirawatana P. Epilepsy awarness among school teacher in Thailand. Epilepsia, 1999; 40 (4): 497-501.

20. Gambhir S K., Kumar V., Singhi P D., Goel R.C. Public awareness, understanding and attitudes toward epilepsy. Indian Journal of Medical Resarch, 1995; 102: 34-8.
21. Lhatoo SD, Sander WAS. The epidemiology of epilepsy and learning disability. Epilepsia, 2001; 42 (Suppl. 1): 6-9.

22. Aldenkamp AP, overweg-Plandsoen WCG, Arends J, An open, nonrandomized clinical comparative study evaluating the effect of epilepsy on learning. J Child Neurol, 1999; 14: 795-800. 

